\title{
Tanduk Alit
}

\author{
Rubrik suplemen yang berisi ringkasan laporan dan output hasil \\ kegiatan pengabdian kepada masyarakat.
}

\section{Resiliensi dengan Shalawat: Pembuatan Buku Shalawat untuk Masyarakat Muslim Pekalongan Selatan dan Timur}

Pelaksanaan kegiatan $\mathrm{PkM}$ dengan tema pembuatan buku shalawat untuk masyarakat muslim di Pekalongan ini dilakukan oleh Prodi Sastra Arab, Departemen Antar Budaya, Fakultas ilmu Budaya, Universitas Gadjah Mada yang dimotori oleh Arief Budiman, Sangidu, dan Hindu. Ide pelaksanaan kegiatan $\mathrm{PkM}$ ini dipicu oleh fenomena adanya kesalahan dalam bacaan shalawat yang dijumpai dan beredar di kalangan masyarakat Pekalongan. Kesalahan tersebut berupa tergantinya satu huruf atau beberapa dengan huruf yang memiliki makhraj (tempat keluarnya huruf) yang berdekatan. Lokasi pelaksanaan ada di dua kecamatan, yaitu kecamatan Pekalongan Selatan dan Timur. Untuk mewujudkan buku shalawat tersebut, tim pelaksana $\mathrm{PkM}$ melakukannya dalam beberapa tahap pelaksanaan program, yaitu tahap pengumpulan data, tahap penyusunan data, tahap penyajian data, dan terakhir distribusi buku dan pendampingan bacaan. Pada akhir kegiatan berhasil disusun 57 jenis shalawat yang berhasil tersusun dengan panjang bait yang beragam dan

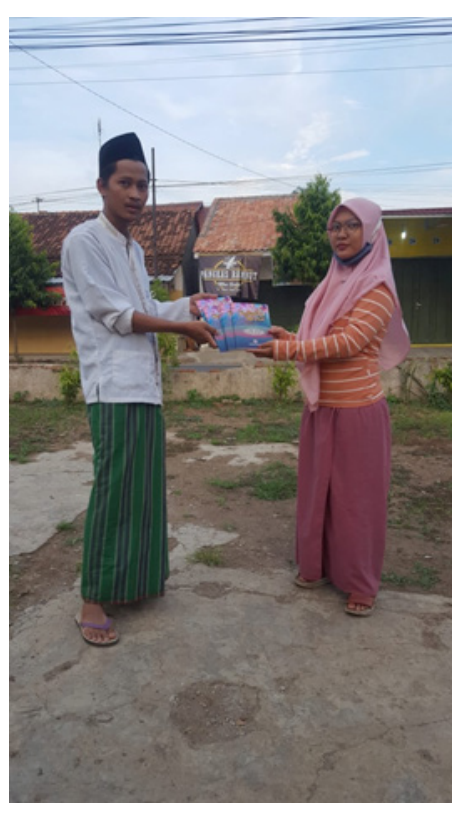

Gambar 1. Penyerahan buku bacaan shalawat kepada masyarakat. yang kemudian dibagikan kepada para pembaca shalawat di masjid dan musholla di Pekalongan Selatan dan Timur. Dampak kegiatan Pk Mini segera terlihat setelah selesainya kegiatan program, terutama dengan adanya variasi ragam bacaan shalawat yang sekarang dimiliki oleh masyarakat di Pekalongan Selatan dan Timur. Selain itu, saat ini pembaca shalawat tidak lagi hanya terpaku dengan apa yang telah dihafalkan, tetapi mereka membaca teks shalawat lain yang telah disediakan dalam buku tanpa adanya kesalahan bacaan. [Disarikan dari artikel laporan PkM yang disusun oleh Arief Budiman]

\section{Revitalisasi Bahasa Jawa Bagi Siswa SLTA di Kabupaten Gunungkidul}

Kegiatan PkM ini dilaksanakan oleh Tim PkM Prodi Sastra Jawa, Fakultas Ilmu Budaya, Universitas Gadjah Mada. Pelaksanaan program PkM ini dilandasi dengan kepedulian terhadap semakin sedikitnya atau bahkan menghilangkan penggunaan istilah dan kosa 


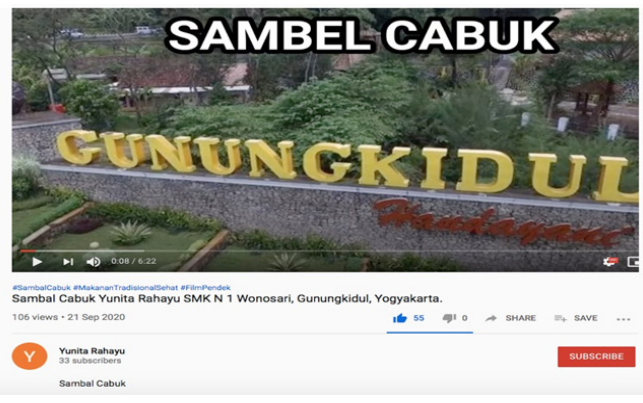

Gambar 2. Contoh hasil pembuatan video oleh siswa dengan tema kuliner (https://youtu.be/68doA03mzrA).

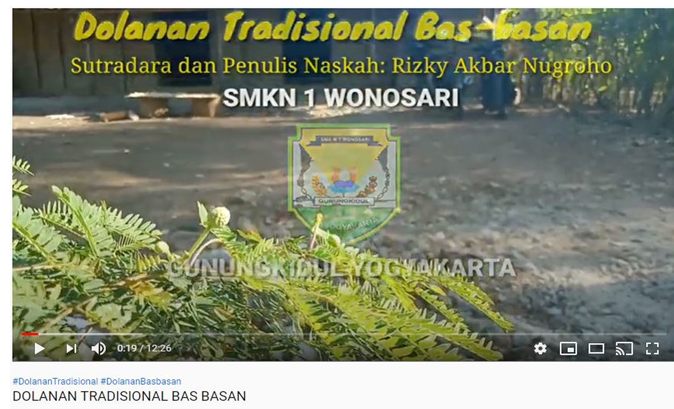

Gambar 3. Contoh hasil pembuatan video oleh siswa dengan tema permainan tradisional (https://youtu.be/oS-WfK5OgRk).

kata Bahasa Jawa yang ada di Gunung Kidul, sehingga perlu dilakukan sebuah upaya revitalisasi. Revitalisasi tidak sekadar mengenalkan kembali kata-kata atau istilah, tetapi mencoba menerapkan penggunaannya dalam kehidupan sehari-hari. Melalui revitalisasi upaya pemeliharaan bahasa atau pemertahanan bahasa (language maintenance) dapat dilakukan.

Program revitalisasi bahasa Jawa di Gunungkidul ini dilakukan oleh Tim PkM melalui kegiatan workshop dengan pola pembimbingan dan konsultasi jarak jauh dengan metode daring (online) dan luring (offline). Metode daring menggunakan aplikasi Zoom, Whatsapp dan email. Peserta terdiri dari 55 siswa SLTA di Gunung Kidul. Materi yang diberikan meliputi proses penggalian kosa kata atau istilah khas Gunungkidul, proses berlatih menerapkan kosa kata atau istilah tersebut dalam kehidupan sehari-hari, dan proses merekam kegiatan menggunakan kamera. Hasil akhir kegiatan ini berupa video penggunaan kosa kata atau istilah khas dalam bahasa Jawa yang dikhawatirkan akan menghilang di Gunungkidul dengan durasi 5-10 menit. Kumpulan video tersebut kemudian diunggah di media sosial youtube agar bisa dikenal di kalangan luas dan dimanfaatkan oleh berbagai pihak.

Hasil Kegiatan PkM ini cukup menggembirakan. Para peserta workshop terlihat antusias dalam menulis dan membuat video. Pada akhirnya, terkumpul sekitar empat puluh lima tulisan yang cukup bervariasi dengan tujuh video yang menunjukkan kemampuan dan kemauan peserta ikut merevitalisasi bahasa daerahnya. Ranah tulisan maupun video yang telah ditulis dan berhasil diupload, di antaranya tentang: makanan, upacara adat, pertanian, dan permainan. Melihat kemauan dan antusiasme siswa SMA tersebut, membangkitkan optimisme bahwa mereka akan menjadi generasi penerus yang akan tetap bangga dan tetap punya keinginan mempertahankan bahasanya. [Disarikan dari artikel laporan PkM yang disusun oleh Daru Winarti, Sulistyowati, dan Sumarsih]

\section{Penguatan Pemahaman Gaya hidup sesuai Protokol Kesehatan di SMA Negeri 1 Sleman}

Kegiatan pengabdian kepada masyarakat $(\mathrm{PkM})$ yang akan dikembangkan oleh Departemen sejarah, Fakultas Ilmu Budaya, Universitas Gadjah Mada mempunyai 


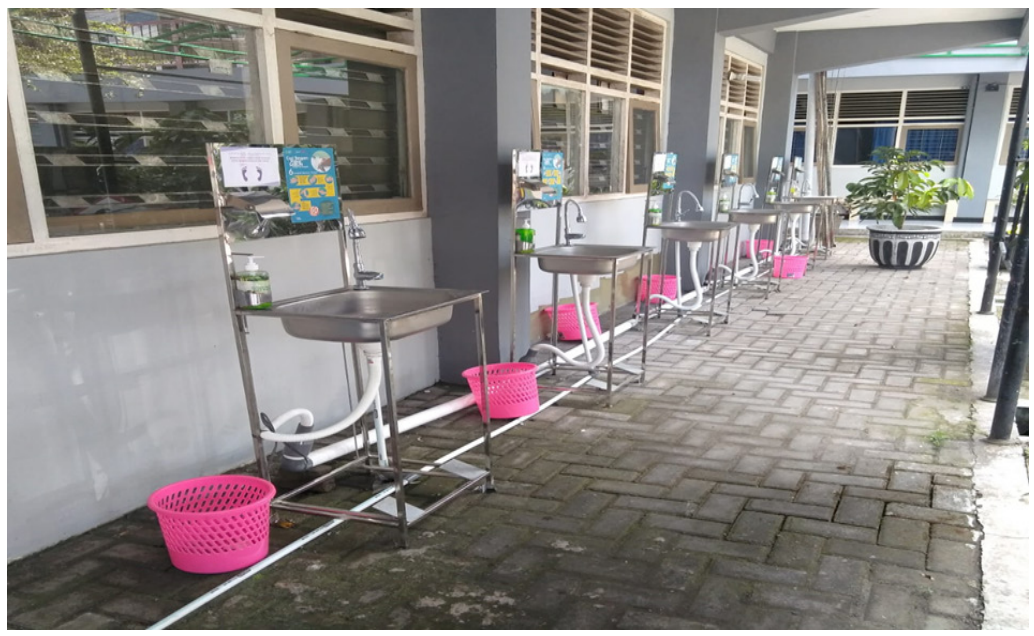

Gambar 4. Fasilitas cuci tangan bagi Guru dan murid di SMAN 1 Sleman

tujuan untuk meningkatkan kesadaran para siswa SMAN I Sleman terhadap pentingnya mengikuti dan mengetahui Protokol Kesehatan untuk bermasyarakat dan sekaligus sebagai sarana untuk memutus rantai penularan Covid 19. Selain itu, tujuan yang lain adalah untuk memberikan pengetahuan metode penulisan essay sejarah covid-19 di kalangan murid-murid SMAN I Sleman. Metode yang digunakan dalam kegiatan PkM kali ini dilakukan dengan dua cara. Pertama, pemberian penguatan pemahaman gaya hidup sesuai protokal kesehatan akan dilakukan dengan metode ceramah dengan materi yang berhubungan dengan penanganan Covid-19. Dalam kesempatan ini, dihadirkan secara daring narasumber dr. Nurul Fitri Syarifah pada hari Kamis, tanggal 9 Juli 2020 yang memberikan penguatan pemahaman gaya hidup sesuai protokol kesehatan. Kedua, pelatihan untuk penulisan sejarah covid-19 di lingkungan sekitar para siswa. Pelatihan penulisan sejarh dilaksanakan oleh tim dengan cara memberikan pemahaman mengenai penulisan sejarah, khususnya sejarah covid-19 yang ada di lingkungan sekitarnya. Setelah pemberian materi sejarah ini dilanjutkan dengan lomba penulisan essay di antara para murid. Penilaian essay siswa dilakukan oleh Tim PkM berdasarkan kriteria penilaian yang sudah disusun, yaitu orisinalitas atau keaslian, pemahaman materi, penyajian, dan kebahasaan. Setelah melakukan penilaian, terdapat 4 essay yang dianggap layak mendapatkan penghargaan, karena memiliki skor yang tinggi. Hasil kegiatan pengabdian kali ini memperjelas sekali bahwa penguatan pemahaman gaya hidup sesuai Protokol Kesehatan dan penulisan sejarah di sekitar lingkungannya yang mereka kenal sangat diperlukan di kalangan para murid SMA. Pelatihan penulisan sejarah dalam bentuk essay di lingkungan sekitar sangat diperlukan untuk melatih menjelaskan fenomena yang terjadi di sekitar para murid SMA. [Disarikan dari artikel laporan PkM yang disusun oleh Nur Aini Setiawati]

\section{Visualisasi Belajar di Rumah BDR bagi Siswa-Siswi Sekolah Dasar Selama Pandemi}

Kegiatan PkM yang dilaksanakan oleh Departemen Antropologi, Fakultas Ilmu Budaya, Universitas Gadjah Mada ini berfokus pada strategi para murid dan orang tua dalam 
menghadapi perpanjangan masa karantina dalam menjalani kegiatan Belajar dari Rumah (BdR). Dengan demikian sasaran program pengabdian kepada masyarakat ini adalah para murid serta orang tua di SDN Percobaan 2 di daerah Mlati, Yogyakarta. Metode yang digunakan dalam pelaksanaan program dilakukan melalui metode diskusi secara daring antara Tim PkM dengan murid dan orangtua yang dihadiri juga oleh guru sekolah. Hasil diskusi FGD menemukan bahwa BdR adalah proses di mana ranah publik yang diwakili oleh ruang kelas harus dipindah secara virtual ke ranah digital dan secara fisik dibawa ke ranah privat di rumah yang berakibat rutinitas seluruh anggota keluarga di rumah jadi berubah. Di samping itu, BdR di era pandemi menunjukkan strategi bagaimana siswa-siswa SD berkompromi dengan orang tua mereka. Sebaliknya orang tua juga menegosiasikan aturan-aturan baru kala semua anggota keluarga berada di rumah tapi dengan status yang terkoneksi ke luar rumah (entah WfH atau BdR). Hasil diskusi juga menunjukkan bahwa saat-saat darurat seperti pandemi ini memunculkan coping mechanism demi kesehatan mental dan moral seluruh anggota keluarga dan ternyata bahwa New Normal itu bukan hanya instruksi dari pihak otoritas, tapi juga merupakan sesuatu yang diciptakan secara mikro di level keluarga. Hasil akhir dari kegiatan PkM ini memberikan kontribusi yang penting dalam pemilihan dan penyusunan strategi siswa SD beserta orangtua dalam menjalani BdR dalam masa pandemi ini. [Disarikan dari artikel laporan PkM yang disusun oleh Suzie Handajani dan Pujo Semedi]

\section{Sinergi Melawan Covid-19}

Tim Pengabdian kepada Masyarakat Program Studi Sastra Arab, Fakultas Ilmu Budaya, Universitas Gadjah Mada (FIB-UGM) melaksanakan program PkM berupa penyampaian bahan pengajian yang dikemas dalam bentuk training of trainers upaya meminimalisasi dampak negatif pandemi covid-19 terhadap jamaah masjid Al-Qomar. Masjid Al-Qomar berlokasi di Dusun Gowok, desa Caturtunggal, Kecamatan Depok, Kabupaten Sleman, Daerah Istimewa Yogyakarta. Di masa pandemi covid-19 ini di masjid Al-Qomar Gowok masih tampak kekurangtertiban sebagaian jamaah untuk menaati prototol kesehatan. $\mathrm{PkM}$ dilaksanakan dengan cara memberikan materi dakwah kepada tim Al-Qomar serta mendiskusikannya. Selanjutnya Risma Al-Qomar menyampaikannya kepada jamaah dalam bentuk kuliah ba'da magrib. Topik materi dakwah terdiri atas "Menghindari Rasa Cemas", "Makanan Halal dan Haram Menurut Islam”, “Tidak Saling Menyakiti”, "Bersin”, "Ibadah saat Wabah”, "Bersuci”, dan "Saling membantu”. Semua tema didiskusikan dan hasilnya disampaikan oleh Risma kepada jamaah. Di samping itu, pengurus masjid menyediakan tempat cuci tangan dengan sabun dan air kran yang mengalir serta masker yang diberikan secara gratis. Pada saat dilakukan evaluasi kegiatan program PkM terlihat bahwa Jamaah yang semula masih enggan menaati protokol kesehatan, ketika $\mathrm{PkM}$ ini akan berakhir tidak tampak lagi adanya jamaah yang hadir di masjid tidak menggunakan masker. Mereka juga mulai memanfaatkan washtafel untuk mencuci tangan dengan sabun, melakukan jamaah sholat berjarak sesuai dengan arahan tanda yang ada di lantai, dan tidak berkerumun di masjid. [Disarikan dari artikel laporan PkM yang disusun oleh Amir Ma'ruf] 